\title{
Julia Lovell as a Faithful Rewriter in Translating Chinese Literary Text: The Version of A Dictionary of Maqiao as a Case in Point
}

\author{
QIN Qian, YAN Fang-ming \\ College of Foreign Studies, Jinan University, Guangzhou City, China
}

\begin{abstract}
As a professional translator, Chinese history lecturer and academic writer, Julia Lovell has made a lot of contributions in translating modern Chinese literary works into English. But the field of translation studies has not given due attention to her so far. Based on her own practice and understanding of translation, she presented the notion of faithful recreation as her translation principle. This article sheds light on how she implemented her translation notion in the process of her translation, taking her version of A Dictionary of Maqiao as a case to examine the effectiveness of her work under the guidance of faithful recreation. The discussion mainly focuses on the sound level, the grammatical level, pragmatic level, and original creativity.
\end{abstract}

Keywords: translation principle, faithful recreation, creativity, effectiveness

\section{Introduction}

Julia Lovell, the British writer and literary translator, is a lecturer in Chinese history at the University of London. She started learning Chinese during her Cambridge University study and in 1997 she studied at Nanjing University for one year as an exchange student. From this period, she became interested in modern Chinese literature, which intrigues her to devote to translating Chinese literary works in the later period. Her translation mainly focuses on the modern Chinese works, including Han Shaogong's A Dictionary of Maqiao (2005), Xinran's Sky Burial (2004), Zhu Wen's I Love Dollars (2006), Eileen Chang's Lust, Caution (2007), Yan Lianke's Serve the People (2008), and Lu Xun's The Real Story of Ah-Q and Other Tales of China (2009). But now for the invitation of Penguin group she is translating 西游记 (Xi You Ji, Journey to the West), one of the four major Chinese classic novels. But up to now, Julia Lovell's contribution in translating modern Chinese literary works has not gained due attention of translation criticism. In addition to translation, she also contributed a lot as an academic writer. Her own works mainly include The Politics of Cultural Capital: China's Quest for a Nobel Prize in Literature (2006), The Great Wall: China Against the World 1000 BC-AD 2000 (2006) and The Opium War: Drugs, Dreams and the Making of China (2011).

The English version of Han Shaogong's A Dictionary of Maqiao is her first work in translating Chinese novels. She recalled that "I still remember how immediately appealing I found Han Shaogong's writing when I read him for my Master's degree” (YANG, 2010). That is the reason why she chose to translate this book. Even

QIN Qian, M.A., Lecturer , College of Foreign Studies, Jinan University.

YAN Fang-ming, Ph.D., Associate Professor, College of Foreign Studies, Jinan University. 
after she finished translating this work, no commercial press is interested in publishing it. Only after Columbia University Press published it in a limited number of hard copy, commercial publishers became aware of its commercial potential and bought the rights for the paperback version. Julia later concluded that only when "they saw it (the book) worked, they were prepared to take it on. This is one way in which Chinese literature can enter the publishing mainstream” (YANG, 2010). A Dictionary of Maqiao has helped its author win Best Novel in Taiwan, China Times Prize, Shanghai Literary Prize, Twentieth-Century Chinese Fiction by Asia Weekly and the second Newman Prize for Chinese Literature. The narrative method of this novel is highly praised as being creative by literary critics. "As its title suggests, the novel is structured as a dictionary" (HAN, 2005, p. viii). Under every seemingly dialect dictionary entries, readers can enjoy stories of historical events, people, plants, animals and foods, which form a closely related network of the episodes of Maqiao from pre-1949 to 1976, reflecting the historical changes of China and picturing lives of common Chinese people in this duration. When Julia Lovell wrote to Han Shaogong that she wanted to translate this novel, the writer gave her a "friendly but slightly bemused response, 'I am very happy that you wish to translate the book, but I'm afraid it will be terribly difficult”' (HAN, 2005, p. xiii). To a great extent, this novel is really hard to be rendered into English because of the quantitative uses of dialect and provincial custom in this book. In despite of the great difficulties, Lovell finished her translation successfully except five entries of the novel because she thought they are "so heavily dependent in the Chinese original on puns between dialect and Mandarin Chinese as to make extensive and distracting linguistic explanations necessary in English” (HAN, 2005, p. xiii). In general, the whole version is faithful to the original text. In this article, we want to delve into the skills employed by Julia Lovell guided by her principle of faithful recreation and discuss the effectiveness and losses of her translation work.

Julia Lovell firstly presented her translation principle of "faithful recreation" (LU, 2009, p. xliv) in The Complete Fiction of Lu Xun published in 2009. Before theoretically putting forward this translation principle, she has brought it into play in her translation practice, including the translation of A Dictionary of Maqiao, which attracted lots of readers for the translator's excellent work. The word of "faithful" here carries the meaning of the translator's being faithful to the original text while "recreation" means that she also exerts her creativity in pursuit of ideal translation. By doing detailed comparison between the original and target texts, we can find that the translator invested a lot of effort in keeping balance between being faithful to the original text and catering for the target readers' aesthetic expectation. On the one hand, she gave enough respect to the author of the original. Only “with the author's permission”, she omitted "the following entries: 'Bayuan'; 'Lian xiang'; 'Liu shi'; 'Po nao'; 'Xian'; and the final paragraph of the entry 'Reincarnation”” (HAN, 2005, p. xiii). In the cases when "literal translation is unacceptable" (WANG, 2013), she still tried to "be close to the spirit of the original text by employing a literally unfaithful way” (WANG, 2013). Even in dealing with some aesthetic effects created by special Chinese linguistic devices, she tried her best to cling to the original or make suitable compensation. On the other hand, she consciously or unconsciously made use of recreation in the process of translation in order to provide target readers with "elegant and readable English" (WANG, 2013). The seemly contradictory strategies of faithfulness and recreation were fused together with name of "faithful recreation" as a principle to guide her translating. This article will demonstrate how the translator implemented her translation principle in translating $A$ Dictionary of Maqiao from four aspects, i.e., faithful recreation at the sound level, faithful recreation at the grammatical level, faithful recreation at pragmatic level, and original creativity guided by faithful recreation. 


\section{Faithful Recreation at Sound Level}

The study of a text at the sound level is concerned with the aesthetic effect made by the special pronunciation of words and word combinations. In some texts, especially in literary texts, there may be special sound devices "that can combine to special effect" (Fawcett, 2007, p. 11). In the original text of A Dictionary of Maqiao, the author makes use of some onomatopoetic words to increase the aesthetic value of this text at the sound level. Julia Lovell was especially prudent in dealing with the sound effect created by onomatopoetic words and some Chinese four-word phrases in her faithful recreation work. From the version, it is not difficult to find that the translator showed enough respect to the author in this perspective. Let us look at the following examples concerned with the translator's skills in transplanting the aesthetic values at the sound level.

Example 1:

ST: “凡此百虫, 采天地精华, 集古今灵气, 是最为难得的佳有。佳有。啧啧啧.....” (HAN, 1997, p. 35).

Literal translation: "All these hundreds insects, gathering heaven and earth's essence, collecting ancient and modern spirit, are most delicious dishes. Delicious dishes, Ze, Ze, Ze (pinyin, onomatopoetic word),...”

TT: "The hundred insects are thus, they gather the essence of heaven and earth, collect the ingenuity of the old and the new. They are the most elusive delicacies. Delicacies. Tsk tsk tsk...” (HAN, 2005, p. 36).

Example 2:

ST: 犁完最后一丘晚稻田, 洪老板呼哧呼哧倒在滚惣的泥水里, 再也没有爬起来 (HAN, 1997, p. 205).

Literal translation: Ploughed the last late rice field, boss Hong hu chi hu chi (pinyin) lied down in the hot mud, never climb up again.

TT: After having plough the last paddy of late summer rice, a panting and wheezing boss Hong lay down to sleep in the mud, never to clamber up again (HAN, 2005, p. 207).

In the original text, the author uses onomatopoetic words “啧啧啧 (pronounced as 'ze')” and “呼哧呼哧 (pronounced as 'hu chi hu chi')" to depict the image vividly in these two examples. In the first example the translator creatively coined a word "tsk" to represent the sound and onomatopoetic effects of the original Chinese words. In the second example, the translator partly compensated the sound effect of the original onomatopoetic phrase by using the "panting and wheezing", in which the suffix "-ing” was repeated as the rhetoric device of rhyme. The sound effect and vivid literary images were largely represented in the version.

In the original text the author is in favor of using many four-word phrases to describe the behaviors of people. Of course this linguistic form presents special aesthetic effect for readers. Such phrases may be used in different text types and they are "ideal for creative writing in that they trigger the reader's imagination” (Pellatt \& Liu, 2010, p. 144). It seems that the translator was also fond of the aesthetic effect created by such four-word phrases and tried to represent the original effect in the translated version as shown in the following examples.

Example 3

ST: 万玉还是笼着袖子支支吾吾没有动 (HAN, 1997, p. 60).

Literal translation: Wanyu still put his hands in sleeves, zhi zhi wu wu (pinyin, means staggering) without movement (HAN, 2005, p. 62).

TT: Wanyu just stood there hemming and hawing (HAN, 2005, p. 64). 
Example 4

ST: 我还看见一些面熟和面生的妇人, 村里的和远处来的, 去那里哭哭泣泣, 有的还红了眼睛 (HAN, 1997, p. 66).

Literal translation: I still saw some familiar and unfamiliar women, from the village and other far places, go there ku ku qi qi (pinyin, means crying and crying), some even red eyes.

TT: I also saw women there, both familiar and unfamiliar faces, some form the village and some from far away, all come to weep and wail, eyes red from grief (HAN, 2005, p. 69).

In these examples, the four-word phrase “支支吾吾”, “喊爹喊娘”, and “大叫大喊” are common four-word Chinese phrases while “哭哭泣泣” is temporarily created four-word phrase by the author. These all contributes to describing the repetition of the same actions in the situation, producing aesthetic effects intended by the author. Because of the linguistic differences between Chinese and English it is very difficult even impossible in most cases to transfer the same effect into the target text. In order to represent the original text faithfully the translator employed alliteration and rhyme to compensate the sound effect. In example 3, alliteration and rhyme were used by the translator at the same time while in example 4 only alliteration used. Of course, "translating sounds is actually very difficult” (Fawcett, 2007, p. 13) but they deserve the translator's effort.

\section{Faithful Recreation at Grammatical Level}

Grammar is "the set of rules which determine the way in which units such as words and phrases can be combined in a language and the kind of information which has to be made regularly explicit in utterance" (Baker, 2000, p. 83). It is a relatively stable system that the language users have to follow. In A Dictionary of Maqiao the author employs some novel grammatical devices to show special aesthetic effects, which were sensitively identified by the translator and they were successfully presented in the version.

Example 5

ST: 吃鸡肉鸭肉牛肉羊肉狗肉鱼肉, 还有肉——这是对猪肉的简称。吃包子馒头油饼油糕面条米 粉糍粑, 当然还有饭, 就是米饭 (HAN, 1997, p. 12).

Literal translation: Eat chicken duck meat beef mutton dog meat fish meat and meat-this is pork's abbreviation. Eat stuffed buns steamed buns fried pan cakes fried cookie noodles rice noodles glutinous rice ball, of course, including rice, just is rice.

TT: Qia chicken duck beef mutton fish dog, and meat- this last was the abbreviation for pork. Qia stuffed buns steamed buns fried dough cakes fried crispy cakes noodles rice noodles glutinous rice cakes and, of course, rice (that would be boiled rice) (HAN, 2005, p. 14).

Example 6

ST: 总结出希大杆子道德品质败坏勾结地主恶霸资助土匪武装反对土地改革非常经商等等十来条 罪状, 终于将他定为反动地㾂, 一索子捆了起来 (HAN, 1997, p. 25).

Literal translation: Concluded that Long Stick Xi moral quality bad connect landlord bad guy economically support bandits counter land reform illegally do business and other ten plus crimes, at last made him a counterrevolutionary local ruffians, roped him up.

TT: They got someone highly leaned to mull it all over until he finally concluded that Long Stick Xi was guilty of moral bankruptcy plotting with landlords and tyrants colluding with bandits forcibly resisting land 
reform illegal commerce, and so on, producing a list of crimes ten items long which, inclusion, made him a counterrevolutionary carbuncle who should be tied up double-quick (HAN, 2005, p. 27).

In these three examples, we can see that in the original texts, several related things are put together to form parallelism. The author deliberately deviates from the Chinese grammar by omitting the punctuation in narrating a serial of parallel things. In examples 5 and 6, commas are necessary in the grammatical narration of these underlined parts in the corresponding parts of Chinese and English versions. Such an ungrammatical narration device is a personalized skill coined by the author in order to create a special sound and psychological effects in the readers' minds. In the translated version, the translator successfully identified the author's intention and retained the same grammatical deviation, putting the original text into such ungrammatical expressions as the underlined parts in these two examples. In this way, the sound and psychological effects of the original text were faithfully transferred into the target text. To great extent the translator fulfilled the pursuit of equivalence in narration style presented in the original text.

\section{Faithful Recreation at Pragmatic Level}

As Mona Baker posited that in translation study we should pay attention "not only to denotative meaning but also to 'the way utterances are used in communicative situations and the way we interpret them in context'” (Baker, 2000, p. 217). In translation the translator has to be able to identify the writer's special communicative skill and its pragmatic effect. In many cases it is not very difficult for the translator to reach this target but it is hard to be transplanted in the target text. As we know, Chinese and English are from different language families. This makes the E-C and C-E translation more difficult than the translation between two related languages originated from the same origin, such as English and French. Thus, it is more difficult for translator in dealing with the pragmatic effects created by special linguistic expressions in A Dictionary of Maqiao. Please look at the following examples:

\section{Example 7}

ST: 他眨眨眼: “不叫拖拉机? 我没读多少书, 是个流讯。” 他的意思是, 他是个文盲, 分不清坦 克和拖拉机没有什么奇怪 (HAN, 1997, p. 180).

Literal translation: He blinked: “not called tractor? I didn’t read too many books, I am a rascal.” His meaning is, he is an illiterate, cannot distinguish tank and tractor no wonder.

TT: He blinked: “Isn’t it called tractor? I didn’t get much education, I’m illegitimate.”

What he meant was he was illiterate, that it wasn't surprising he couldn't distinguish clearly between tanks and tractors (HAN, 2005, p. 182).

Example 8

ST: 有一次从公社干部那里, 把毛主席语录“路线是个纲, 纲举目张”, 听成“路线是个桩, 桩上钉 桩”, 有明显的错误, 但因为 “桩”字处于他的口, 马桥人后来一直深信不疑, 反而嘲笑我们知青把路线 说成是“纲”, 纲是什么? (HAN, 1997, p. 180).

Literal translation: Once from the commune cadres, regarded Chairman Mao's quotation "Route is an outline, outline set subject unfold", heard as "route is a stake, stake on nail stake", exists apparent mistake, but because "stake" was from his mouth, Maqiao people later always deeply believe without doubt, but laughed us intellectual youths regarded route as "outline”, outline is what? 
TT: Once, listening to the commune cadres, he heard "We must grasp the key to the road ahead " as "We must grasp the tree on the road ahead", which was obviously wrong, but since "tree" came straight out of Benyi's mouth, Maqiao people trusted it implicitly and instead laughed us Educated Youth, saying we had to grasp the "key" to the road ahead- what was that supposed to mean? (HAN, 2005, pp. 182-183).

In example 7, the pronunciation of “流讯 (rascal)” is similar to “文盲 (illiterate)" in the original text. The speaker mistakes “流讯 (rascal)” with “文盲 (illiterate)”, making a laugh stock for the listeners as well as showing the identity of himself as an illiterate. But if the translator literally puts these two phrases into English, the English version is sure to lose the pragmatic effect of the original text because it is impossible to produce the similar humorous effect by using "rascal” and "illiterate" in English. Therefore, the translator creatively changed the phrase of “流讯 (rascal)” into "illegitimate”, which shares similar pronunciation of "illiterate” and can well retain the original pragmatic effect. In this case, the literal meaning of “流讯 (rascal)” is substituted by "illegitimate". The author successfully represented the original pragmatic effect by recreation instead of falling into the trap of word-for-word translation.

In example 8, the hero of the story makes a mistake in forwarding a quotation of Mao Zedong because of his ignorance and the similar pronunciations of “纲 (principle)” and “桩 (pile)” in Chinese. For the same reason as demonstrated in example 7, the translator tactically changed these pair of word into "key" and "tree" in order to represent the pragmatic effect. In such a case, it would be impossible for the target text to show the original pragmatic effect if the translator cannot do suitable adjustments in the process of translation. In contrast to the literal faithfulness, the process of recreation plays better part in representing the original pragmatic effect. In this respect, it is more like the principle shown in Nida's dynamic equivalence, which places priority on "the way in which the original receptors understood and appreciated the text” (Nida, 2001, p. 86).

\section{Original Creativity Guided by Faithful Creativity}

“Translation is, of course, a rewriting of an original text" (Lefevere, 2004, preface). The translator's creativity is inevitably involved in this process, especially in translating literary text. In seeking for faithfulness, Julia Lovell subjectively employed her own creativity in representing the original aesthetic effect in translating $A$ Dictionary of Maqiao. In addition to that, the translator made use of creativity to add aesthetic value which does not exist in the original text. For example:

Example 9

ST: “什么科学? 还不就是学懒? 你看你们城里的汽车、火车、飞机, 哪一样不是懒人想出来的? 不是图懒, 如何会想出那样鬼名堂?”(HAN, 1997, p. 40).

Literal translation: "What science? Just is learning laziness? You look at your city's car, train, plane, which is not lazy people think out? Not for laziness, why can think out that kind of devilish things?"

TT: "What d'you mean scientific? You mean lazy! Those city automobiles, railroads, flying machines of yours -name me one that hasn’t been thought up by a lazybones! Who else but lazybones wouldn't thought up such a devilish set of names?” (HAN, 2005, p. 42).

Example 10

ST: 各种下流话可以让你大胆得让你目瞪口呆魂飞魄散天旋地转日月无光 (Han, 1997, p. 94). 
Literal translation: All kinds of low talks are bold to make your eyes stare mouth stop soul fly soul disperse sky swirl earth turn sun moon no light.

TT: The endless variety of low talk would make your eyes pop, jaw drop, mind blow, thoughts wander, make the heavens spin, the earth turn, and the sun and moon darken (HAN, 2005, p. 94).

As we can see in example 9, there is no deviated expression and special aesthetic effect in the original text while in the target text the translator creatively puts the word “飞机 (plane)” into “flying machines”. The original word is just a common one carrying no added aesthetic value in the context. But the translator tactically rendered it into an uncommon phrase "flying machines", adding more aesthetic weight. In this case, "the translator's invisibility” (Venuti, 2004, p. v) was totally cast away, contributing to profiling a more vivid image of the undereducated speaker and creating better aesthetic effect in contrast to the original text. In this respect, it is apparently a successful example branded with the author's original creativity.

In example 10, the phrase of “口朵 (mouth stops)” is part of the Chinese idiom “目瞪口朵”, which is employed by the translator to depict the exaggerated effect produced by some local people's low talks. If we put it into English literally, “目瞪口呆” should be “eyes pop, mouth stops”. In this version, the translator creatively put it into "jaw drop", which not only vividly represented the image of this Chinese idiom but also added more poetic effect in this context compared with the original text. Such example shows the translator's proficiency in making use of her own creativity in literary translation. In this respect, her subjectivity is brought into full play skillfully.

\section{Conclusion}

By careful comparison between Chinese and English versions of A Dictionary of Maqiao, we can find that the translator successfully implemented her translation principle of faithful recreation, being faithful to the original text as well as taking target readers' expectation into serious consideration. Henceforth, the seemingly contradictory strategies of faithfulness and recreation are unified in her translating work. The principle of faithful recreation is similar to the notion "loyalty" put forward by Nord, which "commits the translator bilaterally to both the source and the target side” (Nord, 2001). Based on the correct understanding and being faithful to the original text's meaning and aesthetic effect, the translator also employed her own creativity to make the version elegant. In translating some special linguistic and cultural points, she took advantage of "flexible technique to let the readers understand the meaning" (WANG, 2013). Under the guidance of faithful recreation, the gifted translator successfully represented aesthetic effect of the original text to a great extent.

In an interview concerned with her translating Chinese modern literary works, Julia Lovell said that "my fundamental principle overall was, of course, fidelity to the original” (Abrahamsen, 2009). Meanwhile, she also attempts to "get closer to recreating the native speaker's experience reading the original" (Abrahamsen, 2009). In order to let the readers enjoy linguistic fluency, she tries to "avoid using explanatory footnotes wherever possible" (Abrahamsen, 2009). But when it was necessary she would not refuse using "footnotes, or even the occasional introductory note to add information that might be useful or interesting” (Abrahamsen, 2009) for the English readers. It is of no doubt that the translator fulfilled her pursuit very well. But we still can find some losses in this version due to the linguistic and cultural gaps between English and Chinese. I believe that such difficulties can be minimized if the translator made more effort in the course of translation. But such cases are unavoidable in most of the translation work because of the inherent uncertainty of literary translation. 


\section{References}

Abrahamsen, E. (2009). Interview: Julia Lovell. Retrieved from http://paper-republic.org/ericabrahamsen/inter-view-julia-lovell/

Baker, M. (2000). In other words: A coursebook on translation. Beijing: Foreign Language Teaching and Research Press/Routledge.

Fawcett, P. (2007). Translation and language: Linguistic theories explained. Beijing: Foreign Language Teaching and Research Press.

HAN, S. G. (1997). 马桥词典 (A dictionary of Maqiao) (Chinese version). Beijing: The Writers Publishing House.

HAN, S. G. (2005). A dictionary of Maqiao (English version). (J. Lovell, Trans.). New York: The Dial Press.

Kruger, H. (2013). The translation of cultural aspects in South African children's literature in Afrikaans and English: A micro-analysis. Perspectives: Studies in Translatology, 21(2), 156-181.

Lefevere, A. (2004). Translation, rewriting and the manipulation of literary fame. Shanghai: Shanghai Foreign Language Education Press.

LU, X. (2009). The real story of Ah-Q and other tales of China: The complete fiction of Lu Xun. (J. Lovell, Trans.). London: Penguin Group.

Nida, E. A. (2001). Langauge and culture: Contexts in translating. Shanghai: Shanghai Foreign Language Education Press.

Nord, C. (2001). Loyalty revisited: Bible translation as a case in point. The Translator, 7(2), 185-202.

Pellatt, V., \& Liu, E. T. (2010). Thinking Chinese translation. London \& New York: Taylor and Francis Group.

Vanuti, L. (2004). The translator's invisibility: A history of translation. Shanghai: Shanghai Foreign Language Education Press.

WANG, B. R. (2013). 鲁迅小说英译面面观: 蓝诗玲访谈录 (Several aspects about the translation of Lu Xun’s novels: An interview with Julia Lovell). 编译论从 (Compilation and translation review), 6(1), 147-167.

YANG, G. (2010). Establishing a bond with Chinese writing. Retrieved from http://www.chinadaily.com.cn/life/2010-08/30/content_11222704.htm 